Transducers for Microprocessor Systems 
Other books by the same author

Electronic Computers (Oliver and Boyd)

Computer Interfacing and On-Line Operation (Crane, Russak, New York)

Electronic Equipment Reliability (Macmillan)

Programming for Minicomputers (Crane, Russak, New York/Arnold)

Electrical Drawing I (Macmillan)

Interfacing to Microprocessors (Macmillan)

Other Macmillan books of related interest

G. B. Clayton, Data Converters

B. A. Gregory, An Introduction to Electrical Instrumentation and Measurement Systems, second edition

N. M. Morris, Microprocessor and Microcomputer Technology

B. S. Walker, Understanding Microprocessors 


\title{
Transducers for Microprocessor Systems
}

\author{
J.C. Cluley \\ M.Sc., C.Eng., M.I.E.E., F.B.C.S.
}

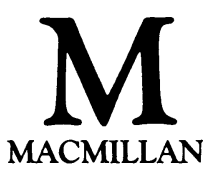


(C) J. C. Cluley 1985

Softcover reprint of the hardcover 1st edition 1985 978-0-333-38565-4

All rights reserved. No reproduction, copy or transmission of this publication may be made without written permission.

No paragraph of this publication may be reproduced, copied or transmitted save with written permission or in accordance with the provisions of the Copyright Act 1956 (as amended).

Any person who does any unauthorised act in relation to this publication may be liable to criminal prosecution and civil claims for damages.

First published 1985

Published by

Higher and Further Education Division

MACMILLAN PUBLISHERS LTD

Houndmills, Basingstoke, Hampshire RG21 2XS

and London

Companies and representatives

throughout the world

Printed in Hong Kong

British Library Cataloguing in Publication Data

Cluley, J. C.

Transducers for microprocessor systems.

1. Transducers 2. Microprocessors

I. Title

001.64'4 TK7895.T7

ISBN 978-0-333-38566-1 ISBN 978-1-349-86023-4 (eBook)

DOI 10.1007/978-1-349-86023-4 


\section{Contents}

Preface viii

List of Abbreviations ix

1 The Role of Transducers in Microprocessor Systems 1

1.1 Introduction 1

1.2 The function of transducers 2

1.3 Transducer dynamic response 3

1.4 Transducer resolution 4

1.5 Economic factors 5

2 Signal Representation and Coding 7

$\begin{array}{lll}2.1 & \text { Analogue and digital signalling } & 7\end{array}$

2.2 Signal coding 8

2.3 Conversion between analogue and digital signals 9

$\begin{array}{ll}2.4 & \text { DAC conversion times } \\ 2.5 & 12\end{array}$

$\begin{array}{lll}2.5 & \text { ADC interfacing } & 14\end{array}$

$\begin{array}{ll}2.6 & \text { Use of program interrupts } \\ 2.7 & 16\end{array}$

$\begin{array}{ll}2.7 \text { Sample-and-hold circuits } & 17\end{array}$

$\begin{array}{ll}2.8 \text { Sensing switch action } & 18\end{array}$

$\begin{array}{ll}2.9 \text { Coping with switch bounce } & 19\end{array}$

$\begin{array}{ll}2.10 \text { Digital signal levels } & 20\end{array}$

$\begin{array}{ll}2.11 \text { Avoiding noise and interference } & 21\end{array}$

3 Microprocessor Interfaces $\quad 24$

3.1 The use of programmable packages $\quad 24$

$\begin{array}{lll}3.2 & \text { Input/output instructions } & 25\end{array}$

$\begin{array}{lll}3.3 & \text { Parallel interface packages } & 27\end{array}$

3.4 The 8255 Programmable Peripheral Interface 28

$\begin{array}{lll}3.5 & \text { The Z8420 PIO } & 29\end{array}$

$\begin{array}{ll}3.6 & \text { Counter-timer packages } \\ \end{array}$ 
4 Transducers for Linear and Rotary Movement 32

4.1 Coded plate transducers $\quad 32$

4.2 Code conversion by look-up table 35

$\begin{array}{lll}4.3 & \text { Incremental shaft encoders } & 37\end{array}$

4.4 Moiré fringe measurements 39

4.5 Inductive counting systems $\quad 39$

$\begin{array}{lll}4.6 & \text { Potentiometer sensors } & 40\end{array}$

4.7 The linear variable differential transformer 42

4.8 Capacitance sensing $\quad 44$

4.9 Ultrasonic beam sensing $\quad 45$

4.10 Measuring moving objects $\quad 46$

5 Temperature Measurement $\quad 47$

5.1 The platinum resistance thermometer 47

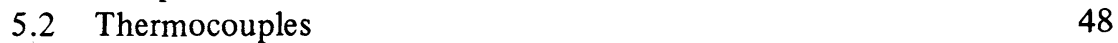

5.3 Thermistors and other devices 49

6 Force and Pressure Transducers 53

6.1 Strain gauges for force measurement 53

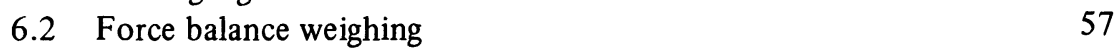

$\begin{array}{lll}6.3 & \text { Pressure measurement } & 57\end{array}$

6.4 Resonant beam sensors $\quad 59$

7 Flow Measurement $\quad 60$

$\begin{array}{lll}7.1 & \text { Digital flowmeters } & 60\end{array}$

$\begin{array}{lll}7.2 & \text { Pressure sensing flowmeters } & 61\end{array}$

$\begin{array}{lll}7.3 & \text { Ultrasonic flow measurement } & 64\end{array}$

$\begin{array}{lll}7.4 & \text { Thermal flow transducers } & 66\end{array}$

$\begin{array}{lll}7.5 & \text { Use of correlation techniques } & 66\end{array}$

8 Velocity and Acceleration Measurement 69

8.1 Measuring rotational speed 69

8.2 Tachometer generators 71

8.3 Using motor e.m.f. to measure speed 72

8.4 Linear velocity measurement 73

8.5 Doppler speed measurement $\quad 74$

8.6 Measuring acceleration 75

9 Proximity Sensing $\quad 78$

9.1 Applications of proximity sensing 78

9.2 Inductive and capacitative proximity sensors 79 
9.3 The Hall effect and its applications $\quad 79$

$\begin{array}{lll}9.4 & \text { Touch pads } & 81\end{array}$

$\begin{array}{lll}9.5 & \text { Standing wave sensors } & 82\end{array}$

10 Data Collection Systems $\quad 84$

$\begin{array}{ll}10.1 \text { Optical sensing } & 84\end{array}$

$\begin{array}{ll}10.2 \text { Serial data input } & 85\end{array}$

$\begin{array}{ll}10.3 \text { Synchronous operation } & 87\end{array}$

$\begin{array}{ll}10.4 \text { Bar code readers } & 88\end{array}$

$\begin{array}{ll}10.5 \text { Magnetically recorded data } & 90\end{array}$

11 Output Transducers 91

$\begin{array}{ll}11.1 \text { Power requirements } & 91\end{array}$

$\begin{array}{ll}\text { 11.2 Switched mode operation } & 93\end{array}$

$\begin{array}{ll}11.3 \text { Triac and thyristor control } & 95\end{array}$

$\begin{array}{ll}11.4 \text { Analogue outputs } & 98\end{array}$

$\begin{array}{lr}11.5 \text { Stepping motors } & 99\end{array}$

$\begin{array}{ll}11.6 \text { Future prospects } & 101\end{array}$

$\begin{array}{ll}\text { Bibliography } & 103\end{array}$

$\begin{array}{ll}\text { Index } & 105\end{array}$ 


\section{Preface}

Many of the millions of microprocessors that are produced every year are used as the controlling elements in industrial plant, test equipment, domestic appliances, chemical plant, material handling equipment etc. To fulfil their allotted role the microprocessor systems need to collect data on external conditions and states such as temperature, pressure, force, velocity, torque and flow rate. These are not electrical quantities and thus transducers are required to transform these variables into electrical signals which the microprocessor system can deal with.

Also the microprocessor may be designed to modify some of these quantities in order to perform its control function; again transducers must be attached to the output circuits of the microprocessor.

The selection of suitable transducers is often a critical factor in the design of microprocessor systems, and a knowledge of the types available, their performance and relative cost is essential for engineers involved in design and development.

Unfortunately, since most transducers are not essentially electronic in nature, few courses in electronic engineering devote much time to a study of transducers and their applications. I have tried in this book to give an overall picture of the range and variety of transducers that may be needed in microprocessor systems, an outline of their main characteristics, and the way in which they can be interfaced to typical microprocessors.

For completeness I have included a chapter that gives a brief description of the more important interface packages used to connect transducers to the microprocessor. Readers requiring further details of interfacing or the way in which microprocessors handle information may find it helpful to consult companion Macmillan books: my own Interfacing to Microprocessors, and Understanding Microprocessors by B. S. Walker.

I hope that students of electronic engineering and practising engineers involved in the design of microprocessor systems and instrumentation will find in this book a useful introduction to the selection and application of transducers.

J. C. CLULEY 


\section{List of Abbreviations}

ACIA Asynchronous Communications Interface Adapter

ADC Analogue-to-Digital Converter

BCD Binary Coded Decimal

CMOS Complementary Metal Oxide Silicon

CPU Central Processor Unit

CR Control Register

DAC Digital-to-Analogue Converter

DDR Data Direction Register

DMA Direct Memory Access

LCD Liquid Crystal Display

LED Light Emitting Diode

LS Least Significant

MS Most Significant

PIA Peripheral Interface Adapter

PIO Parallel Input/Output Controller

PPI Programmable Peripheral Interface

RAM Random Access Memory (Writable Storage)

ROM Read-Only Memory

VDU Visual Display Unit 